\title{
Description and biological notes of the first species of Xenos (Strep- siptera: Stylopidae) parasitic in Polistes carnifex F. (Hymenoptera: Vespidae) in Mexico
}

\author{
JEYARANEY KATHIRITHAMBY ${ }^{1} \&$ DAVID P. HUGHES ${ }^{2}$ \\ ${ }^{1}$ Department of Zoology, South Parks Road, Oxford, OX1 3PS, U.K. \\ jeyaraney.kathirithamby@zoo.ox.ac.uk \\ ${ }^{2}$ Present address: Centre for Social Evolution, Institute of Biology, University of Copenhagen, Univer- \\ sitetsparken 15, 2100 Copenhagen, Denmark \\ dphughes@bi.ku.dk \\ Correspondence:JeyaraneyKathirithambyDepartmentofZoology,SouthParksRoad,OxfordOX13PS, UK. \\ e-mail: jeyaraney.kathirithamby@zoo.ox.ac.uk
}

\begin{abstract}
A description and biological notes on the first species of Xenos (X. hamiltoni) (Strepsiptera: Stylopidae) parasitic in Polistes carnifex F. from Mexico is given. A list of Strepsiptera and their hosts from Mexico is provided.
\end{abstract}

Key words: Strepsiptera, Xenos hamiltoni sp. n., Polistes carnifex, Mexico

\section{Introduction}

To date thirteen species of Strepsiptera have been described from Mexico. Kifune \& Brailovsky (1988) listed eleven and Kathirithamby \& Moya-Raygoza (2000) listed twelve, and since then one subspecies has been added (Kathirithamby \& Johnston 2003). Of these, only one species, Melittostylops vesparapium Kinzelbach, belongs to the family Stylopidae (Kinzelbach 1971). The eighteen species of Xenos described so far from the Neotropics have been found to be parasitic in the eusocial Hymenoptera: Vespidae (Polistes, Mischocyttarus, Apoica and Polybia) (Kathirithamby 1992).

\section{Material and Methods}

A total of 8 nests of Polistes carnifex were collected between $27^{\text {th }}$ April and $13^{\text {th }}$ May 2001 